\title{
A QUANTITATIVE STUDY OF THE URINARY EXCRETION OF HYPOPHYSEAL GONADOTROPIN, ESTROGEN, AND NEUTRAL 17-KETOSTEROIDS OF NORMAL MEN
}

\author{
BY SIDNEY C. WERNER \\ (From the Departments of Medicine and Neurology, College of Physicians and Surgeons, \\ Columbia University, New York City)
}

(Received for publication November 27, 1942)

The urinary output of hypophyseal gonadotropin by normal women has proven exceedingly variable from month to month $(1,2)$. Thus, the usefulness of gonadotropin assays for clinical purposes has been disappointing and is now limited to the demonstration of large excesses of hormone.

The status of the gonadotropin assay as a potential diagnostic measure in men is still in doubt. More normal data are needed to detail the normal range of excretion and to settle the disagreement between Harris and Brand (3) and Heller, Heller, and Severinghaus (4), concerning the presence of a cycle in men. Accordingly, the present study was undertaken. Concurrent assays of estrogens and neutral 17-ketosteroids were done to determine any correlation with gonadotropin output. The output of these sex hormones follows the pattern described by Gallagher, et al. (5), except that in their studies androgens were assayed in capons.

\section{MATERIALS AND METHODS}

All urine specimens were complete 48-hour collections, kept in cork or glass stoppered bottles, containing 10 to 15 cc. chloroform. The urine was placed in contact with the preservative immediately on voiding. In most instances, the bottles were kept in the cold during collection. The chloroform is important since it limits the toxicity of the gonadotropic extracts prepared by tannic acid precipitation, without interfering with the colorimetric reaction for 17-ketosteroids. A rubber stopper is probably not desirable since chloroform can dissolve material from the stopper which may be chromogenic in the Zimmermann reaction. The methods of extraction and assay in this study were entirely similar to those previously reported (1), with the exception of several modifications made in the 17-ketosteroid reaction, to conform with the method of Callow, Callow, and Emmens (6), as detailed elsewhere (7). The final color was read in an Evelyn colorimeter, using filters at 520 and 440 millimicra to check the purity of each extract (8). Hypophyseal gonadotropin was prepared by tannic acid precipitation and was assayed by the mouse uterine weight method of Levin and Tyndale (9). Estrogen assays were conducted by the method of Kahnt and Doisy (10) on tested castrate rats. To insure uniformity of response, animals from a special colony of mice of the Swiss strain and rats of the Long-Evans strain were used. The mice were repeatedly tested for sensitivity to urinary gonadotropins with a constant weight of a castrate urine preparation, furnished by Dr. Louis Levin of the Anatomy Department; the rats were standardized for estrogen response with crystalline estrone. 1 Except for a definitely increased sensitivity in the summer months, both groups of animals showed a uniform response throughout the year. The mouse unit for gonadotropin was not considered positive unless 2 of 3 mice showed uterine weights greater than 0.0135 gram at autopsy. This weight was never seen in control mice with initial body weights of less than 12 grams at 22 days of age, and then autopsied at the same age as the test mice. A rat unit varied between 0.4 and 0.7 gamma of estrone, averaging about 0.6 gamma. This average was slightly less than that of the same colony during 1939 and 1940. Extracts were generally kept in the ice-box in a dry state, tightly stoppered, and for no more than 3 weeks before dissolving for assay. No significant change in potency has been noted to occur with storage of other specimens up to 6 months.

\section{RESULTS}

The urine which was assayed was collected from 5 healthy, normal men, and was their entire output during the period of the experiment. The subjects carried on their daily routine, except that subjects N. J. and N. V. were undergoing a correlative psychologic study by Dr. George Daniels, of the Department of Psychiatry, during the period of the experiment. All remained healthy. The ages were $21,22,23,24$, and 33 years. Only subject $\mathrm{N}$. D. was married.

The hormonal output of each of the 5 subjects is shown in Figures 1 to 5 . The curves of excretion were approximately the same for all the subjects, except for the striking spurt in gonado-

1 Dr. Edward Henderson of the Schering Corporation furnished the crystalline estrone used in this study. 


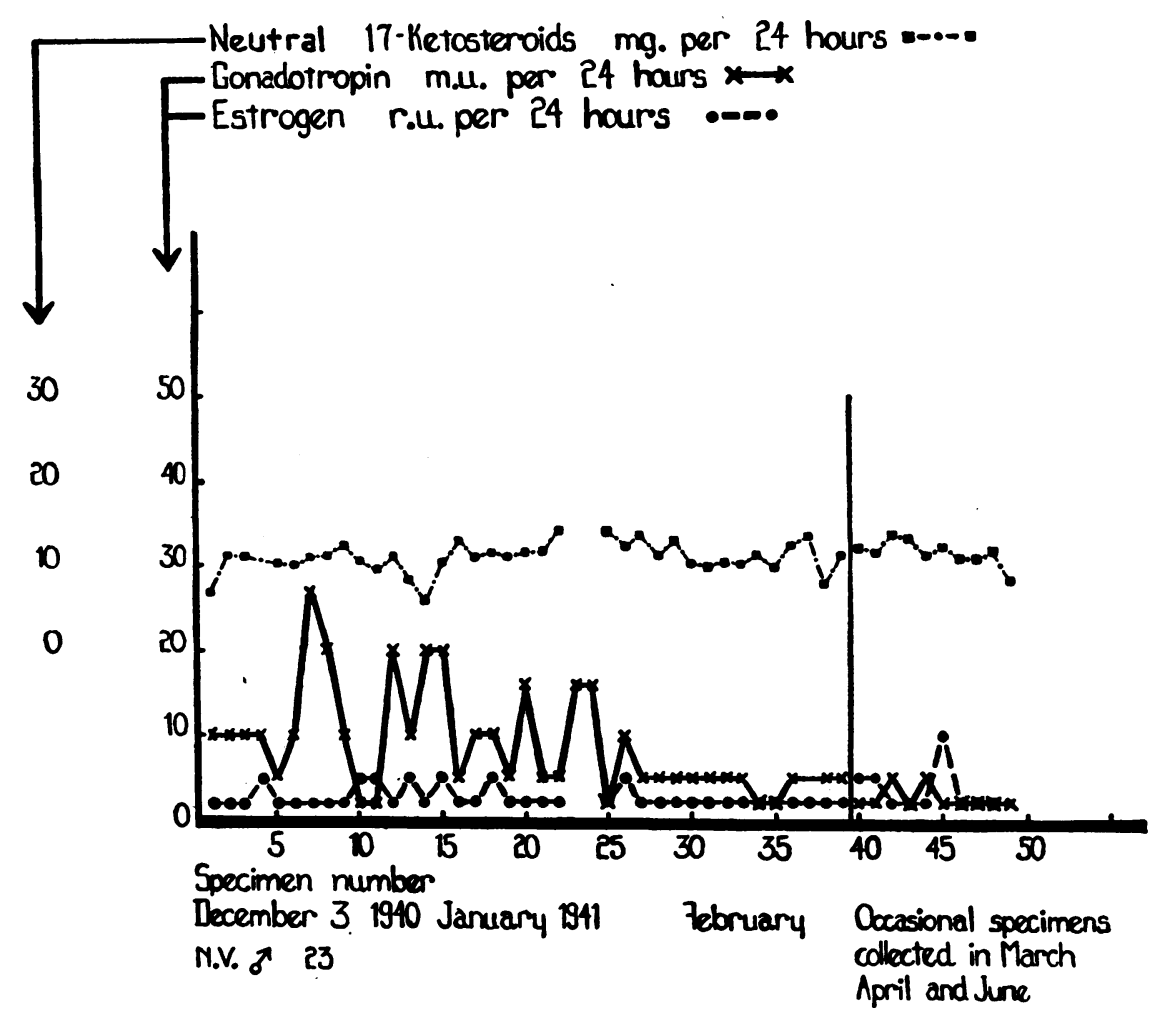

Fig. 1. Forty-Eight Hour Excretion of Gonadotropin, Estrogen, and 17-Ketosteroids in a Normal Male, Showing a Sharp Decline in Gonadotropin and Estrogen Excretion in the Latter Half of the Study. Subject N. V.

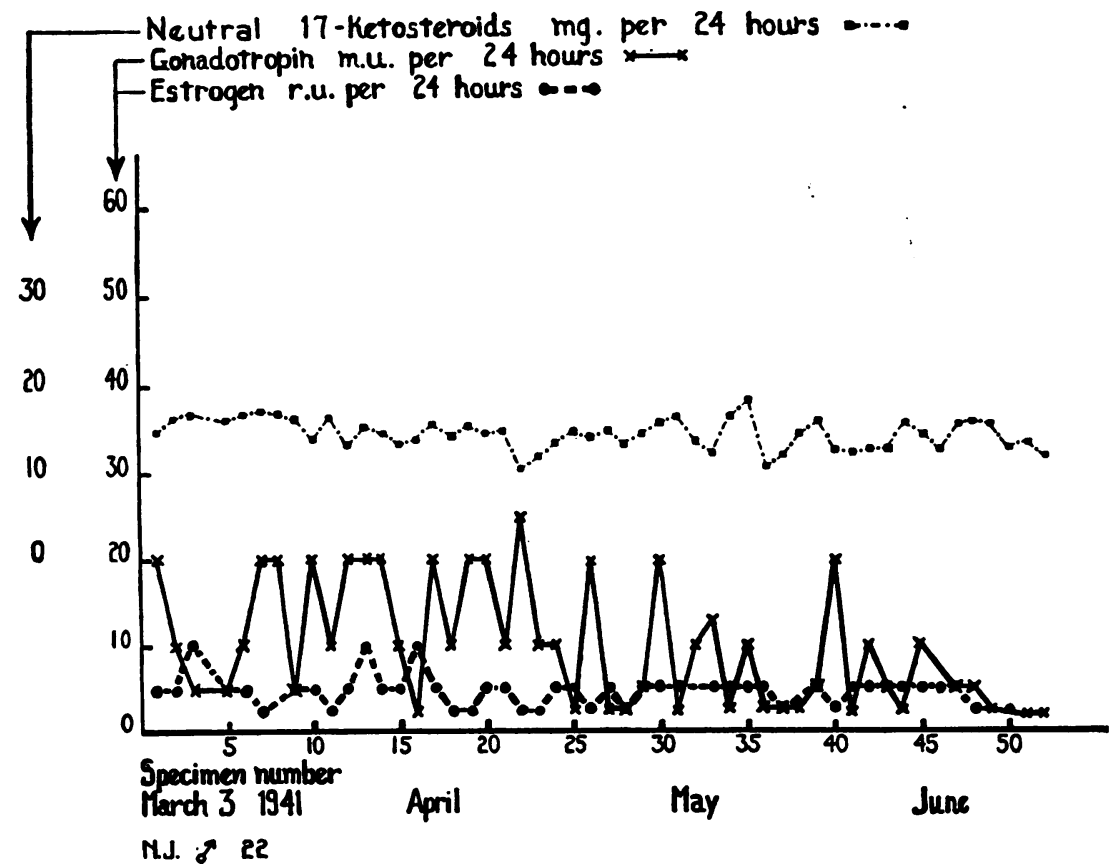

Fig. 2. Forty-Eight Hour Excretion of Gonadotropin, Estrogen, ANd 17Ketosteroids Showing a Decline in Gonadotropin Excretion Without Corresponding Change in Estrogen. Subject N. J. 


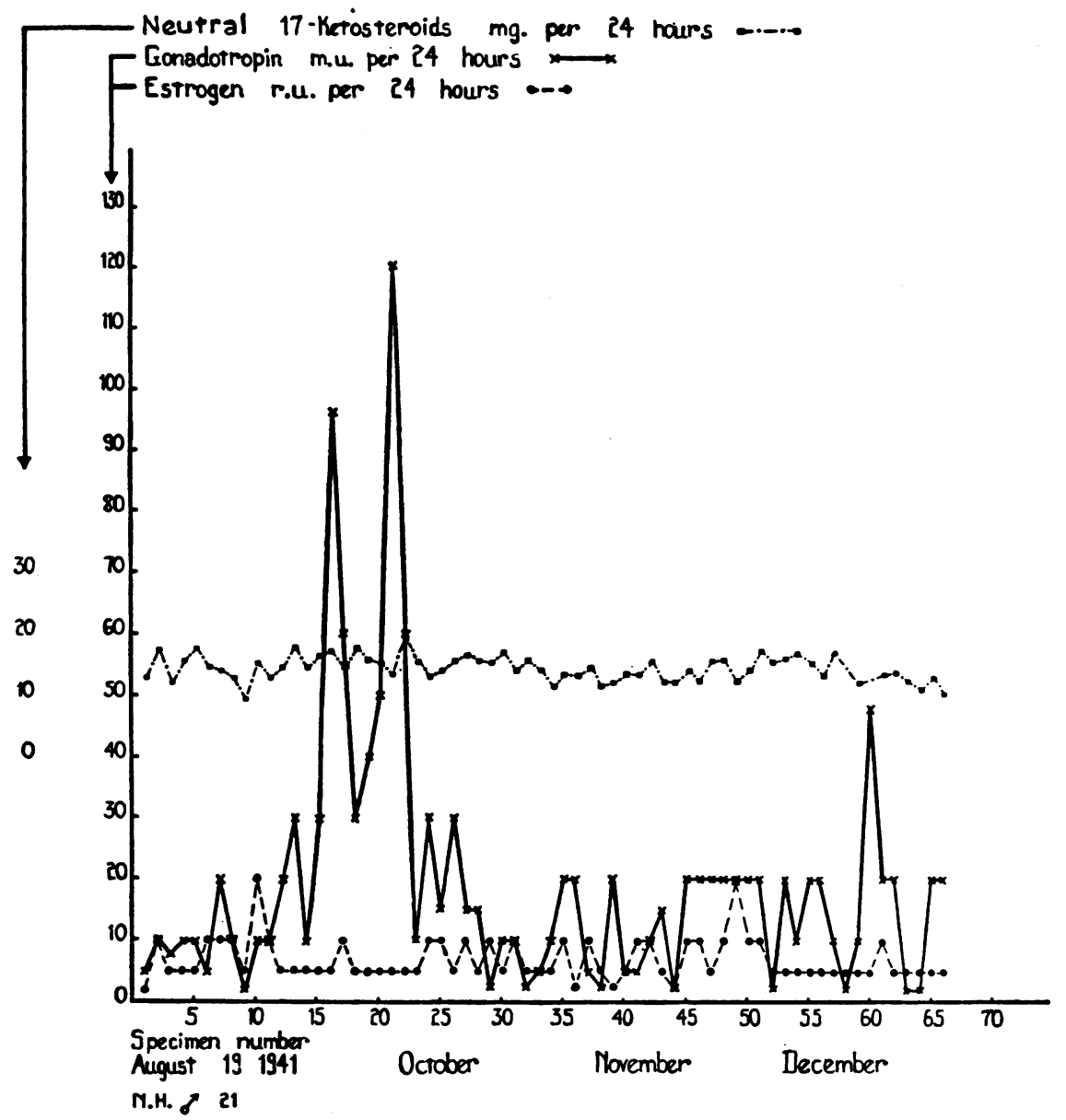

Fig. 3. Forty-Eight Hour Excretion of Gonadotropin, Estrogen, and 17Ketosteroids Showing a Sharp and Prolonged Spurt in Gonadotropin Excretion. SubJect N. H.

tropin excretion shown by $\mathrm{N}$. H. and the later decline in gonadotropin output of both N. J. and N. V. The average estrogen output was consistently greater in some than in others. The daily output showed extreme variability in all the subjects. The 17-ketosteroid excretion fluctuated from day to day within relatively narrow limits, but the average output varied between individuals.

Gonadotropin. Gonadotropin was usually demonstrable in all subjects (Figures, and Table I). The daily excretion varied from less than a demonstrable amount (i.e. less than 5 m.u.) to as much as 120 m.u. per 24 hours. The values rarely exceeded 40 m.u. per 24 hours, however. In the figures, values between 0 and 10 m.u. mean that the assay for the higher figure was negative and could not be made for lower values because of toxicity of some of the extracts. Thus, values below 10 mouse units are not quantitatively accurate.

Over long periods, the average gonadotropin output showed great fluctuation. In subject $\mathrm{N}$. $\mathrm{V}$, the excretion during the first month and a half was approximately double that of the second period. Similar high or low levels, lasting several weeks, occurred in the other subjects. This was especially striking in subject $\mathrm{N}$. H. There is no suggestion of periodicity or rhythmicity to these changes. The two peaks of excretion, occurring about a month apart, in subject N. D. might have been thought to indicate some periodicity as suggested by Harris and Brand (3). Because these peaks did not subsequently reappear, their significance remains in doubt. The spurt in gonadotropin excretion by subject $N$. H. in the first few 


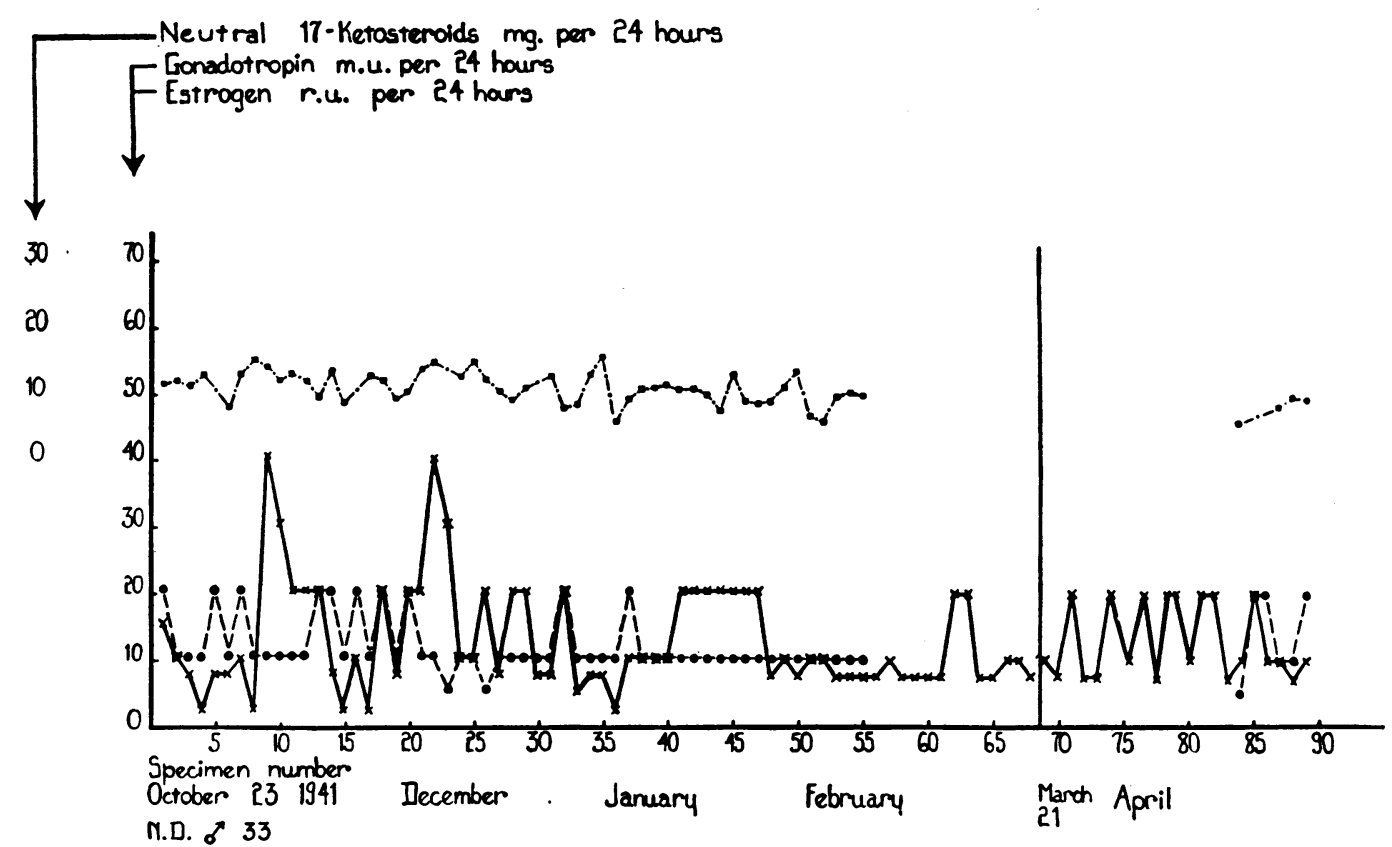

Fig. 4. Forty-Eight Hour Excretion of Gonadotropin, Estrogen, and 17-Ketosteroids Showing Fluctuations in Gonadotropin and Estrogen Excretion Over Long Periods, and Illustrating 2 Recurrent Peaks of Gonadotropin. Subject N. D.

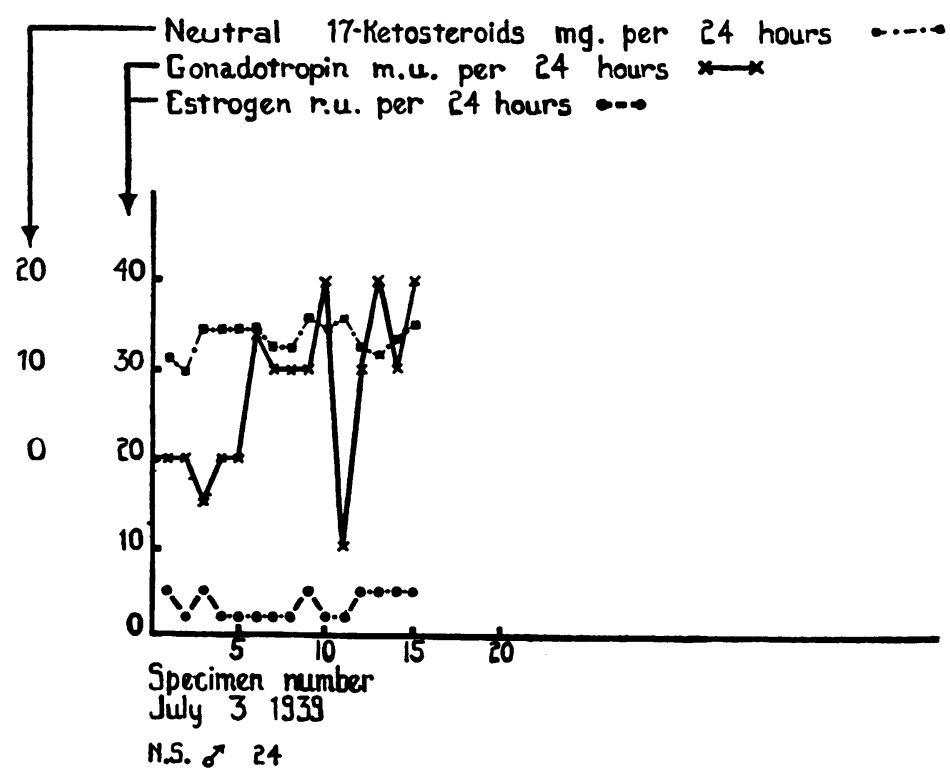

Fig. 5. Forty-Eight Hour Excretion of Gonadotropin, Estrogen, and 17-Ketosteroids Showing a Prolonged Spurt in Gonadotropin ExCRETION. SUbJECT N. S.

weeks of the study is noteworthy and is discussed below. This sharp increase was not reduplicated in this or in the other cases.

Estrogen. Estrogen values represent the total of free and combined estrogen (11). No attempt was made to separate the various estrogens. Extracts which did not give a response equal to 5 units or more are considered to be zero. The long term average excretion of estrogen differs greatly between subjects. Not only is the daily variation 
TABLE I

Range of normal values for the excretion of gonadotropin, estrogen, and neutral 17-ketosteroids

\begin{tabular}{|c|c|c|c|c|}
\hline Subject & $\begin{array}{c}\text { Gonado- } \\
\text { tropin }\end{array}$ & Estrogen & $\begin{array}{l}\text { 17-keto- } \\
\text { steroids }\end{array}$ & $\begin{array}{l}\text { Estrogen-17- } \\
\text { ketosteroid }\end{array}$ \\
\hline $\begin{array}{l}\text { N. S. } \\
\text { Average }\end{array}$ & $\begin{array}{c}\text { mouse units } \\
\text { per } 84 \text { hours } \\
10 \text { to } 40 \\
25.3\end{array}$ & $\begin{array}{c}\text { rat units } \\
\text { per } 84 \text { hours } \\
<5 \text { to } 5 \\
2.3\end{array}$ & $\begin{array}{c}\text { mgm. } \\
\text { per } 24 \text { hours } \\
11.3 \text { to } 15.9 \\
13.6\end{array}$ & $\begin{array}{l}\text { ratio } \\
0.17\end{array}$ \\
\hline $\begin{array}{l}\text { N. J. } \\
\text { Average }\end{array}$ & $\begin{array}{c}<5 \text { to } 20 \\
10.9\end{array}$ & $\begin{array}{c}<5 \text { to } 10 \\
4.3\end{array}$ & $\begin{array}{c}10.1 \text { to } 18.1 \\
14.4\end{array}$ & 0.30 \\
\hline $\begin{array}{l}\text { N. V. } \\
\text { Average }\end{array}$ & $\begin{array}{c}<5 \text { to } 20 \\
8.2\end{array}$ & $\begin{array}{c}<5 \text { to } 10 \\
0.95\end{array}$ & $\begin{array}{c}6.0 \text { to } 14.4 \\
11.1\end{array}$ & 0.09 \\
\hline $\begin{array}{l}\text { N. D. } \\
\text { Average }\end{array}$ & $\begin{array}{c}<5 \text { to } 40 \\
12.0\end{array}$ & $\begin{array}{l}<5 \text { to } 30 \\
11.7\end{array}$ & $\begin{array}{c}5.1 \text { to } 15.2 \\
10.3\end{array}$ & 1.14 \\
\hline $\begin{array}{l}\text { N. H. } \\
\text { Average }\end{array}$ & $\begin{array}{c}<5 \text { to } 120 \\
14.8\end{array}$ & $\begin{array}{c}<5 \text { to } 20 \\
6.4\end{array}$ & $\begin{array}{c}7.3 \text { to } 19.3 \\
14.3\end{array}$ & 0.45 \\
\hline $\begin{array}{r}\text { Range for } \\
\text { series }\end{array}$ & $<5$ to 120 & $<5$ to 30 & 5.1 to 19.3 & 0.09 to 1.14 \\
\hline
\end{tabular}

in estrogen excretion tremendous, but the average excretion over long periods also differs. Subject N. D., for example, excreted about twice as much as subject $\mathrm{N}$. $\mathrm{H}$. over an equal length of time. The average output of the same individual over periods of several weeks may change, as is shown in the values obtained during the first and second halves of the assays of subject N. V. (Figure 1). The individual values for the series ranged from less than 5 r.u. to 30 r.u. per 24 hours (roughly less than 30 to 180 i.u. per 24 hours) (Table I). The average output of the various subjects varied from less than 0.95 to 11.7 r.u. per 24 hours (from 6 to 70 i.u. per 24 hours) (Table I).

Neutral 17-ketosteroids. The figures for 17ketosteroid excretion for the first 2 months in subjects N. S. and N. V. were reported elsewhere to demonstrate that the day to day variation of \pm 40 per cent about the mean, which normally occurs in both men and women, is due to an actual fluctuation in excretion of 17-ketosteroids (7), and not to non-specific chromogens also present in urine. In the present study, the average of the daily outputs was constant for an individual but varied between subjects. The range of excretion for the series was $5.1 \mathrm{mgm}$. to $19.3 \mathrm{mgm}$. per 24 hours. The averages for the various subjects varied between $10.3 \mathrm{mgm}$. and $14.4 \mathrm{mgm}$. per 24 hours.

\section{DISCUSSION}

Data have been obtained showing the quantitative excretion of gonadotropin, estrogen, and 17- ketosteroids by 4 medically normal men, during 3 or more months, and by one man for one month. Two facts stand out from this study. (1) There is a marked and unrelated, day to day variation in output of hypophyseal gonadotropin, estrogen, and 17-ketosteroids. (2) There is a striking fluctuation in the excretion of gonadotropin over longer periods. There is no evidence of any cycle in the excretion of any of these hormones.

The reason for the fluctuation in the levels of gonadotropin is difficult to determine. The question immediately arises as to whether this fluctuation is due to a real increase in excretion of hormone as the result of a physiological change, or is due to an apparent increase in excretion caused by spontaneous variations in the sensitivity of the assay animals. The honesty of all donors seems unquestionable and there seems no likelihood of the specimens having come from some other source, either accidentally or deliberately. Periodic testing of the mice throughout the year with a standard weight of gonadotropic material, obtained from a castrate urine preparation, reveals a significant increase in the sensitivity of the mice toward the end of the summer. The sensitivity is, however, quite constant through the rest of the year (Table II). The mice were not especially sensitive when tested at the time of the very high values displayed by subject $\mathrm{N}$. H. Therefore, these values appear to be real. However, the fact that the high titer did not reappear during the next 8 months was disappointing if the initial spurt is to be accounted for on a physiological basis. Whether the spectacularly high values are real or not, the fluctuations in average gonadotropin values over various periods must reflect a true physiological change in view of the occurrence of this phenomenon in all subjects. The evaluation of abnormal excretion of gonadotropin by present technics must take into account these normal variations, whether due to physiological change or the result of limitations of the biological method.

It becomes clear that the clinical value of hormonal assays in men, as in women, is subject to sharp limitations because of this variability in the normal hormonal output. A marked increase in the excretion of these hormones can be established by a few tests, but a subnormal output can be determined only after a long series of assays. Random samples over several weeks from a 
TABLE II

Mouse uterine weight response to a constant test dose of castrate urine principle

\begin{tabular}{|c|c|c|c|c|c|c|c|}
\hline \multirow{2}{*}{ Date of assay } & \multirow{2}{*}{$\begin{array}{c}\text { Prepara- } \\
\text { tion } \\
\text { number }\end{array}$} & \multirow{2}{*}{$\begin{array}{c}\text { Number } \\
\text { of } \\
\text { mice }\end{array}$} & \multirow{2}{*}{$\begin{array}{l}\text { Range of uterine } \\
\text { weight response }\end{array}$} & \multicolumn{2}{|c|}{ Vaginal response } & \multicolumn{2}{|c|}{ Type response } \\
\hline & & & & Open & Closed & $\begin{array}{l}\text { Number } \\
\text { positive }\end{array}$ & $\begin{array}{l}\text { Number } \\
\text { negative }\end{array}$ \\
\hline October 17,1941 & L $610 \mathrm{~K}$ & 12 & $\begin{array}{c}\text { grams } \\
0.0087 \text { to } 0.0192\end{array}$ & 2 & 10 & 7 & 5 \\
\hline November 8,1941 & L $610 \mathrm{~L}$ & 9 & 0.0096 to 0.0221 & $\mathbf{0}$ & 9 & 7 & 2 \\
\hline February 13,1942 & L $610 \mathrm{M}$ & 9 & 0.0043 to 0.0263 & $\mathbf{0}$ & 9 & 7 & 2 \\
\hline 21,1942 & L $610 \mathrm{~N}$ & 9 & 0.0117 to 0.0330 & $\mathbf{0}$ & 9 & 7 & 2 \\
\hline 5,1942 & $\mathrm{~L} 610 \mathrm{O}$ & 9 & 0.0095 to 0.0296 & $\mathbf{0}$ & 9 & 7 & 2 \\
\hline September 17, 1942 & L $610 \mathrm{P}$ & 9 & 0.0165 to 0.0354 & 6 & 3 & 9 & $\mathbf{0}$ \\
\hline October & $\begin{array}{l}\mathrm{L} 610 \mathrm{Q} \\
\text { Average }\end{array}$ & 18 & $\begin{array}{c}0.0096 \text { to } 0.0470 \\
0.0218\end{array}$ & 8 & 10 & 15 & 3 \\
\hline
\end{tabular}

normal individual (subject N. J.) revealed less than a determinable amount of gonadotropin. In establishing the presence of a disturbance which might be expected to cause a decrease in gonadotropin output, such as anterior hypopituitarism, it becomes evident that more than an occasional negative value is needed. To undertake a series of assays sharply limits the feasibility of this procedure as an aid in diagnosis. The same applies to estrogen assays. However, relatively few tests are necessary to determine an abnormal change in the 17 -ketosteroid excretion.

Individual or average estrogen and 17-ketosteroid values show no correlation, either with gonadotropin output or with each other. The estrogen: androgen ratio (5), reveals a tremendous variation from day to day in the same person. Thus, it does not appear to have any value in clinical practice.

The average values for 17 -ketosteroid excretion fall within the range of output of normal women (1). This does not fit with the generalization of Fraser et al. (12) who postulate that men excrete more than women, on the ground that an equal fraction of the $17-$ ketosteroid excretion is derived from the adrenal cortex in both sexes, whereas the men excrete an additional amount from the testes.

A word of discussion concerning assay methods is in order since these undergo such frequent revision. For example, the colorimetric determination of the neutral 17-ketosteroids, a more or less standardized chemical procedure (6), has been recently extended to include fractionation of these steroids $(13,14)$, and this fractionation will probably be adopted for routine use. The determination of estrogen or gonadotropin, as yet a biological procedure, is in an even greater state of flux. For the estrogens, the principles of extraction are generally agreed upon, but a number of assay methods are in use (15). For gonadotropin determination, the lack of agreement includes both extraction and assay (16).

The tannic acid procedure has been used in this study in preference to the alcohol precipitation method. Assays have been possible in unpublished work for as low as 2.5 m.u. per 24 hours, and almost invariably for 10 m.u. per 24 hours. Such results are as good, if not better, quantitatively, than those of other methods. No loss of potency is indicated (17), and less toxicity has been observed. Smaller amounts of alcohol are necessary than with the alcohol precipitation method, and the method is quicker, since dialysis of the precipitate is not necessary. The tannic acid method also permits the assay of estrogen and androgen on the same specimen, which is not possible with alcohol precipitation. A possible objection is raised by Evans (18) who has stated that follicle stimulating and luteinizing fractions may not be precipitated equally by tannic acid as compared to alcohol.

A review of the control data from the mouse assays with the same preparation of gonadotropin 
reemphasizes the necessity of having an adequate number of test animals to assay the extracts. The value of a one-animal assay is obviously very slight, and even a 3-mouse test may give a positive, negative, or markedly positive result with the same dosage. It is, therefore, advisable to use at least 9 mice, in groups of 3 , testing the suspected unit level and a level on either side, so that a more positive, and a completely negative, group confirm the result. The other alternative is to use large numbers of animals at a given dose level. Less than 5 m.u. can rarely be tested because of toxicity, so that only 2 groups of 3 mice, for 5 and 10 units, have been employed at this unit level. In any event, a 24 - or 48-hour collection is necessary to furnish enough extract to assay for these lower values. The same applies to the estrogen assays in rats. It is also advisable to use the various dose levels soon after their preparation, since aqueous gonadotropin solutions slowly lose potency. This is an important factor if several reassays are necessary, especially in the warm months.

\section{SUMMARY}

The urinary output of hypophyseal gonadotropin, estrogen, and 17-ketosteroids of 4 normal men has been assayed over a period of 3 months or more, and of one man for a period of one month. Marked fluctuations are noted when the outputs of gonadotropin over relatively long periods are compared, and a similar variation is noted over shorter periods in estrogen and 17ketosteroid excretion. No correlation is found between the output of gonadotropin, estrogen, and 17-ketosteroids. An increase in sensitivity of the mouse uterine test has been found to occur in the late summer. The implications of the above are discussed.

The author is indebted to Dr. P. E. Smith for his advice and to Miss E. Zabriskie and Mrs. B. Myer for technical assistance.

\section{BIBLIOGRAPHY}

1. Werner, S. C., A quantitative study of the urinary excretion of hypophyseal gonadotropin, estrogen and androgen of normal women. J. Clin. Invest., 1941, 20, 21.
2. D'Amour, F. E., Funk, D., and Liverman, H., Daily gonadotropic hormone tests during 50 complete cycles. Am. J. Obst. and Gynec., 1939, 37, 940.

3. Harris, M. M., and Brand, E., The existence of a monthly sex cycle in the human male. Science, 1934, 79, 364.

4. Heller, E. J., Heller, C. G., and Severinghaus, E. L., Gonadotropic hormone: assays of human male urine. Endocrinology, 1941, 29, 1.

5. Gallagher, T. F., et al., The daily urinary excretion of estrogenic and androgenic substances by normal men and women. J. Clin. Invest., 1937, 16, 695.

6. Callow, N. H., Callow, R. K., and Emmens, C. W., Colorimetric determination of substances containing the grouping $-\mathrm{CH}_{2} . \mathrm{CO}-$ in urine extracts as an indication of androgen content. Biochem. J., 1938, 32, 1312.

7. Werner, S. C., The daily variation in 17 -ketosteroid excretion of men and women. J. Clin. Endocrinol., 1941, 1, 951.

8. Talbot, N. B., Berman, R. A., and MacLachlan, E. A., Elimination of errors in the colorimetric assay of neutral urinary 17-ketosteroids by means of a color correction equation. J. Biol. Chem., 1942, 143, 211.

9. Levin, L., and Tyndale, H. H., The quantitative assay of " follicle stimulating" substances. Endocrinology, 1937, 21, 619.

10. Kahnt, L. C., and Doisy, E. A., Vaginal smear method of assay of ovarian hormone. Endocrinology, 1928, $12,760$.

11. Smith, G. V., and Smith, O. W., The quantitative determination of urinary oestrin. Am. J. Physiol., 1935, 112, 340.

12. Fraser, R. W., et al., Colorimetric assay of 17 -ketosteroids in urine. J. Clin. Endocrinol., 1941, 1, 234.

13. Talbot, N. B., Butler, A. M., and MacLachlan, E. A., The colorimetric assay of total, alpha and beta 17ketosteroids in extracts of human urine. J. Biol. Chem., 1940, 132, 595.

14. Talbot, N. B., et al., Chromatographic separation and colorimetric assay of alcoholic and non-alcoholic 17-ketosteroids in extracts of human urine. J. Biol. Chem., 1941, 139, 521.

15. Varney, R. F., and Koch, F. C., Method for assay of gonadotropin content of normal human urine. Endocrinology, 1942, 30, 339.

16. Heller, C. G., and Heller, E. J., Gonadotropic hormone: clinical application of extraction methods for assay purposes. Endocrinology, 1939, 24, 319.

17. Levin, L., Quantitative precipitation of urinary gonadotropin of normal men and women. Endocrinology, 1941, 28, 378.

18. Evans, H. M., and Gorbman, A., Urinary gonadotrophins in normal men. Proc. Soc. Exper. Biol. and Med., 1942, 49, 674. 